\title{
Influence of Tax, Unemployment and Political Instability to In- donesia Government Expenditures 1988-2016 Period
}

\author{
Sugiartiningsih, Hesty Juny*, Ignatius Oki, Tria Apriliana, Muhammad Ali \\ Faculty of Economics, Widyatama University, Bandung, Indonesia \\ *Corresponding author E-mail: sugiarti.ningsih@widyatama.ac.id
}

\begin{abstract}
This study aims to determine the effect of taxes, unemployment and political instability on Indonesian government spending. The research method used in this study is descriptive analysis method because it is to find out the third causal relationship of independent variables on Indonesian government expenditure. The model is built multiple regression with secondary data boundaries from 1988 to 2016. Based on the results of calculations, the results of a positive relationship between tax and political instability of Indonesian government expenditure are obtained. While, unemployment has a negative relationship to Indonesian government spending. The main factor is the condition of Indonesian unemployment is high, starting from junior high school, vocational high school and even university level. While the government is trying to overcome it, it has not been optimally because of the obstacles in the village and in the city. On the contrary, tax and strong political instability after the reform of Indonesian government spending.
\end{abstract}

Keywords: tax; unemployment; political instability; government expenditures.

\section{Introduction}

The economic welfare of a country is largely determined by government intervention through fiscal policy. Its manifestation is with government spending that is used for routine financing and construction expenditure [4]. The reality of the development process in Indonesia demands the provision of public goods whose value is very high and must be fulfilled by the government immediately. Even the government is often challenged, the need for infrastructure development to accelerate economic growth.
The trend of increasing Indonesian government spending is strongly influenced by the prediction of tax revenues. If we increase tax revenues, then potential government spending will also increase. Other macro factors are unemployment and in Indonesia's political stability. Number of unemployed Indonesia has fluctuated, after the economic crisis has seen an increase. But from 2008 to 2016, there was a decline. This condition will more or less affect the Indonesian government expenditure. Realization of the statement as shown in the following figure. 


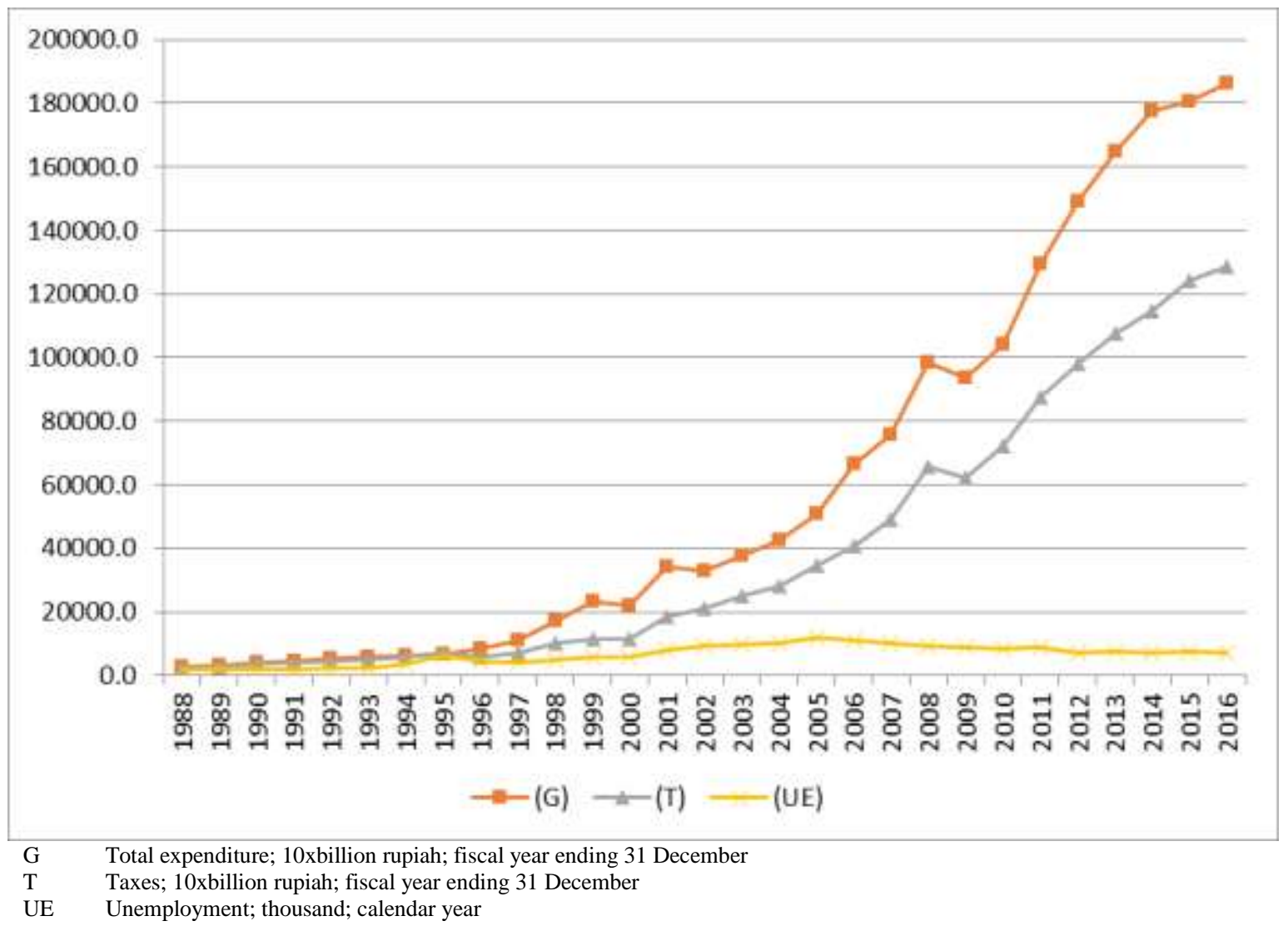

Fig. 1: Total expenditure, taxes and unemployment

Political instability also an important factor to consider in influencing government spending, especially when considering postreform Indonesia there have been many political disturbances. It is probable that if our political stability is fragile, the burden on the government will be heavier as seen from high government spending.

Of the phenomenon, so it is interesting to examine the economic factors of the third ejection Indonesian government a 1988-2014 period.

Based on the description of the background of the problem, the formulation of the problem proposed is: 1) What is the effect of the tax on Indonesian government expenditure for the period 1988-2016; 2) How does the spirit of unemployment over expenditure Indonesian government the 1988-2016 period; 3) How effect the political instability of the Indonesian government expenditure 1988-2016 period; 4) How is the tax effect, unemployment and the political instability of Indonesia government expenditure.

\section{Literature Review}

\subsection{Indonesian Economic System}

The definition of an economic system is simply a system that regulates the economy of a country in order to achieve state goals [1]. The meaning of the economic system aims to answer economic questions, namely what, how and for whom. If all three of these questions were authorized to the government, a country would be considered to adhere to the communist economic system. On the other hand, if the decision making on the three economic problems is left entirely to the market mechanism, it is stated to embrace a pure capitalist economic system. While, the combination of government authority and market mechanisms will bring about a mixed economic or socialist system. The distribution of the three types continues to experience development in accordance with the conditions of each country. In general, developed countries prefer the regular capitalist economic system because they are accus- tomed to the liberal nature but are still subject to government regulations.

The division of the economic system based on the production organization has now given birth to the Islamic economic system and Pancasila. The Islamic economic system which is based on the Al-Quran and Assunah, has premises: human needs must not be excessive, not the principle of scarcity but grateful for God's gift and not just looking for fun but hasanah the afterlife. Then, in its operation the Islamic economic system needs to be based on achieving equal distribution of income and employment opportunities, profits for business actors and efficient and straightforward principles [1].

While the Pancasila economic system has two important characteristics, namely supported by the legal force of Article 33, reinforced by articles 23, 27, 34 and 2 of the 1945 Constitution and based on and imbued with the values of Pancasila. The first precept implies that all economic activities are based on faith and piety. The second precept emphasizes on human nuances when gathering economic relations for the development of society. Third principle emphasizes the principle of unity and through 'gotong-royong' activities. The fifth precept means economic activity must come from the people, by the people and for the people. The fifth precept means economic activity in Indonesia must always be colored by social justice and egalitarian [10].

\subsection{Tax Structure, Unemployment and Government Expenditures}

Tax as an important source of state revenue based on its structure is regulated in the Act No. 25/1999. Where the tax structure is divided into three, namely central, provincial and district / city government taxes. Under this Act, Income Tax $(\mathrm{PPh})$, Value Added Tax (PPN), export tax and import tax are still central taxes that are not distributed to the regions [9].

In connection with Law No. 34/2000 the sources of tax revenue in provinces and districts/cities can be described as follows: Provincial taxes include motorized vehicle tax on water, transfer fees on names of motorized vehicles and vehicles on water, motor vehicle 
fuel taxes and taxes on the extraction and utilization of underground and surface water. District/city taxes include hotel taxes, restaurant taxes, entertainment taxes, advertisement taxes, street lighting tax, tax for the extraction of class $\mathrm{C}$ excavation materials and parking tax [12].

Unemployment is defined as the condition of someone who is of working age and has tried to find work but has not worked. In the macroeconomic perspective, unemployment is divided into two, voluntary and involuntary unemployment. For the category of involuntary unemployment can be distinguished according to the causes namely unemployment conjuncture, structural unemployment and normal unemployment. The three types of unemployment are grouped into open unemployment. Besides open unemployment, in developing countries, other forms of unemployment are obtained, namely: hidden unemployment, unemployment season and underemployment [11].

Government expenditure as a component of APBN in Indonesia during the New Order was divided into two namely routine expenditure and development expenditure. Routine expenditures are divided into five namely: 1) Employee expenditures (salaries and pensions, rice allowances, meal money/side dishes, another DN employee expenditures and expenditure for LN employees); 2) Expenditures of goods (shopping for DN and LN goods); 3) $\mathrm{Au}-$ tonomous area subsidy (employee and non-employee expenditure); 4) Interest and debt installments (domestic and foreign debt); and 5) Other routine expenditures (fuel subsidies and others). Development expenditure is divided into two namely routine assistance and project assistance $[5,12]$.

The government expenditure structure after reform is divided into two namely central government spending and transfers to the regions. Central government spending by type is employee expenditure, domestic and foreign goods expenditure, capital expenditure, debt interest payments, subsidies, grant spending and social assistance. Details of regional transfers include balance funds, special autonomy funds and adjustment funds [1].

Tax as a foundation for state revenue from the government sector is the dominant factor that will increase government spending both for routine expenditure and development expenditure. Thus, if the prediction of a country's high, tax receipts will push the government's ability to improve the government spending.

Unemployment is recognized as a macro disease that must be experienced by every country, the government must pay attention to creating jobs as widely as possible. When oversight unemployment, a high proven state government should increase spending government to resolve it. In the next stage, this will increase government spending [11].

\subsection{Tax Influence, Unemployment and Political Stabil- ity on Government Expenditures}

Government expenditure in a macro perspective is an exogenous variable because it cannot be affected by the size of national income. For this reason, the size of government expenditure will be affected by factors outside national income. Macroeconomic factors that affect a country's government expenditure are: 1) Taxes. The prediction of high tax revenue by a country has the potential to increase financing for routine expenditure and development expenditure. Conditions will be followed by an increase in government spending; 2) Unemployment. In general, unemployment is a major economic problem for a country that cannot be eliminated to zero percent. However, the unemployment must be reduced to be considered safe, by increasing government spending; 3) Political stability. Every country wants good political conditions so that the development process runs smoothly. If a country experiences interference from its political stability, it must be resolved by the government with its considerable expenditure.

\subsection{Framework}

Government expenditure is a reflection of the implementation of fiscal policy by a country. As is known, not a single country is free from the economic problems of the country that are considered dangerous, namely unemployment and stability. With the implementation of the macro disease fiscal policy can be overcome by using variables mainly government expenditure. On the other hand, the government's ability to increase government spending is strongly supported by its tax revenues.

If a country's tax revenue increases, it will help the government finance both routine expenditure and development expenditure. Unidirectional relationship also occurs on both main problem macroeconomics. For reasons of high unemployment and disruption of political stability requires serious government intervention. Implementation by increasing government spending.

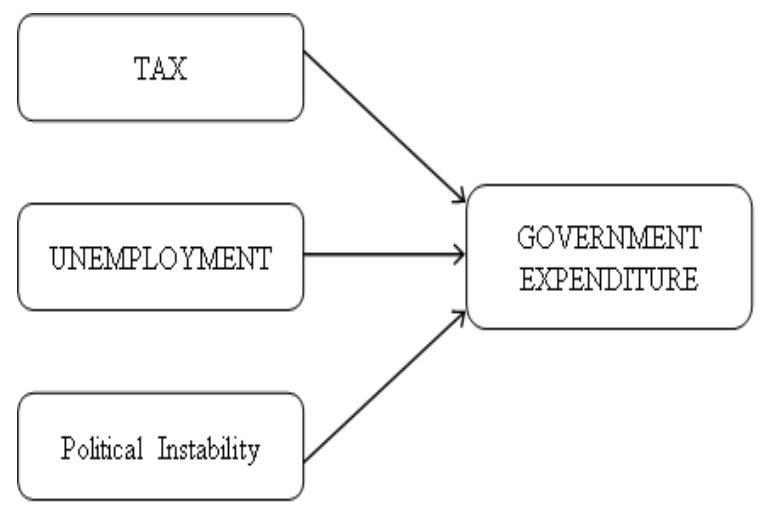

Fig. 2: Tax influence, unemployment and political instability of Indonesian government expenditures

\subsection{Research Hypothesis}

Increased tax revenue in Indonesia will increase domestic financing sources so that it has the opportunity to increase government spending. Research that discusses the relationship between the two variables has been done by the author after the reformation [14] and obtained a positive and significant relationship.

Ha: Taxes will have a positive effect on Indonesian government spending.

Increasing unemployment of a country will encourage the implementation of fiscal policy by the government by increasing government spending to create development programs for Human Resources (HR). Research that discusses the relationship these two variables has been done and the results were positive and significant [14].

Ha: Unemployment will have a positive effect on Indonesian government spending

Increased interference or political instability are obstacles to development that requires government intervention through fiscal policy. The solution is by increasing large government spending. This is in accordance with public economic theory which states that the conditions of war will cause large government spending to improve infrastructure. The research that touched on the theory has been done by the author and gave positive and significant results [13].

Ha: Political instability will be a positive influence on the lawyer e outputs the Indonesian government.

Taxes, unemployment and political instability can all affect the country's economy so that it will affect the government's contribution that is realized in government spending.

Ha: Tax, unemployment and political instability together affect government spending. 


\section{Methodology}

The research method used is a descriptive analysis approach that aims to provide an overview causal relationship between tax, unemployment and political instability with Indonesian government spending. The data used are secondary data from the Asian Development Bank from 1988 until 2016. In 1988 was chosen to coincide with a new policy that is deregulation and 2016 was a big success after the reform of the Indonesian economy [2-3].

Tax relationship modeling, unemployment and political instability with the Indonesian government expenditure 1988-2016 period by using multiple regression equation as below:

$$
G=a+b_{1} T+b_{2} U E+b_{3} S P
$$

where

$\mathrm{G}=$ value of Indonesian government expenditure (currency unit), $\mathrm{T}=\operatorname{tax}$ (currency unit), $\mathrm{EU}=$ unemployment (unit of person) and $\mathrm{SP}=$ political instability (dummy variable, if zero is stable and one is instable).

\subsection{Partial Test of Regression Equations}

Taxes affect Indonesian government spending. $\mathrm{H}_{0}: \rho_{1}<0$ Taxes negatively affect Indonesian government spending.
$\mathrm{H}_{0}: \rho_{1}>0$ Taxes have a positive effect on Indonesian government spending.

Unemployment has an effect on Indonesian government spending.

$\mathrm{H}_{0}: \rho_{2}<0$ Unemployment has a negative effect on Indonesian government spending.

$\mathrm{H} 0: \rho_{2}>0 \mathrm{P}$ unemployment has a positive effect on Indonesian government spending.

Political instability affects Indonesian government spending.

$\mathrm{H}_{0}: \rho_{3}<0$ Political instability negatively affects Indonesian government spending.

$\mathrm{H}_{0}: \rho_{3}>0$ Political instability has a positive effect on Indonesian government spending.

\subsection{Simultan Test Regression Equation}

Taxes, unemployment and political instability affect Indonesian government spending.

$\mathrm{H}_{0}: \rho_{1}, \rho_{2}, \rho_{3}=0$ Taxes, unemployment and political instability together do not affect Indonesian government spending.

$\mathrm{H}_{1}: \rho_{1}, \rho_{2}, \rho_{3} \neq 0$ Taxes, unemployment and political instability together affect a spirit against Indonesian government expenditure.

\section{Results and Discussion}

\subsection{Results}

Table 1: Regression

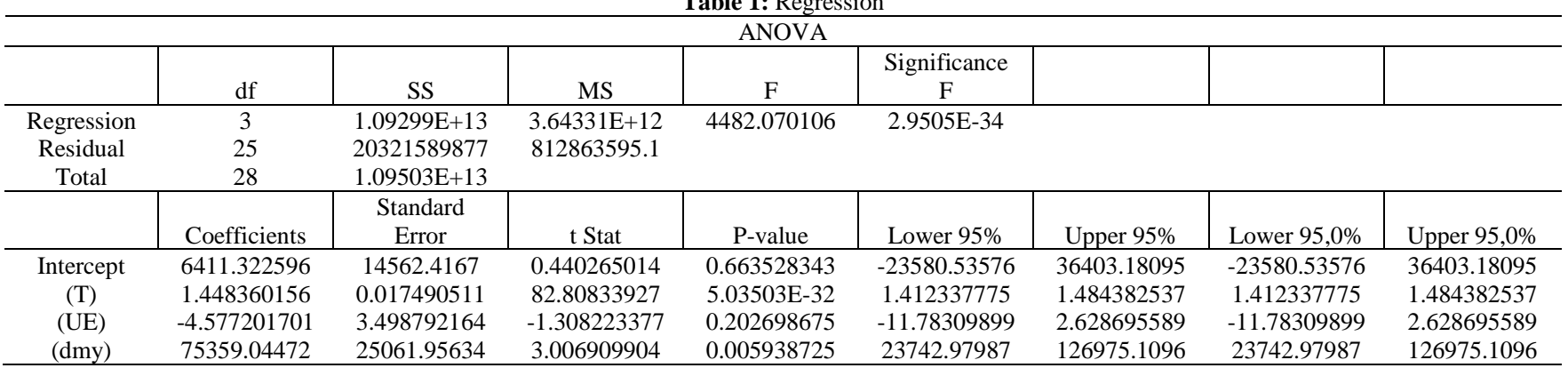

From a tables $\mathrm{T}$ is the tax variable, EU unemployment variable, SP political instability and $\mathrm{G}$ Indonesian government expenditure. If the tax is increased by $\$ 1$ million, the government spending will be increased by $\mathrm{Rp} 1.448360156$ million. If unemployment falls by 1000 people, the government expenditure will increase by Rp 4,577201701 million. If political instability is high, government spending will increase by 75359.04472 .

\subsection{Statistical Testing}

Analysis of the significance of the coefficient of the equation of multiple regression model is done by testing statistical t-test and F-test statistic and determination test.

\subsubsection{Partial Test of Regression Equations}

Ha: Taxes have a positive effect on Indonesian government spending.

Ha: Unemployment has a positive effect on Indonesian government spending.

Ha: Political instability has a positive effect on Indonesian government spending.

From the results of the t-statistical test, the tax variable has a coefficient of 82.8339, unemployment is -1.33682 and political instability is 3.0069 . Tax variables and political instability are proven to have $\mathrm{t}$-count values greater than $\mathrm{t}$-tables on $1 \%$ significance level $(\mathrm{t}$-table $=2.787)$. Whereas, the disturbing variables have a smaller coefficient value than the t-table both at a significance level of $1 \%, 5 \%$ and $10 \%$.

\subsubsection{Simultan Test of Regression Equations}

Ha: Taxes, unemployment and political instability affect Indonesian government spending.

From the results of the F-statistic test obtained coefficient value of 4482,070106. The F-calculated value is proven to be greater than the F-Table value at a significance level of $1 \%(\mathrm{~F}-\mathrm{Table}=4.68)$ [5].

\subsubsection{Determination Test}

Table 2: Determination test

\begin{tabular}{c|c}
\hline \multicolumn{2}{c}{ Table 2: Determination test } \\
\hline \multicolumn{2}{c}{ Regression Statistics } \\
\hline Multiple R & 0.999071664 \\
R Square & 0.998144191 \\
Adjusted R Square & 0.997921493 \\
Standard Error & 28510.76279 \\
Observations & 29 \\
\hline
\end{tabular}

Based on the results calculated in Table obtained Adj $\mathrm{R}^{2}$ value of 0.9979. This means that the three independent variables have a contribution to Indonesian government expenditure of $99.79 \%$. The remaining $0.21 \%$ is another variable outside the regression equation used. 


\subsection{Discussion}

Ha: Taxes have a positive effect on Indonesian government spending

Tax is the main source of financing for the government to improve people's welfare. Since Pelita VI the government has sought to increase the role of direct taxes in optimizing total tax revenue in Indonesia. Entering the SBY I government, Indonesia has succeeded in recording the achievement of direct tax revenues exceeding indirect taxes, thereby increasing tax revenue in Indonesia. The government's target of the tax is to facilitate infrastructure in rural and urban areas to spur our economic growth in the future. As is known in recent years, Indonesia's economic growth stagnated by around $5 \%$. To be able to achieve the $7 \%$ target, massive government spending is needed. Thus, the potential for tax increases will increase the Indonesian government spending.

Ha: Unemployment has a negative effect on the Indonesian government

Indonesian unemployment even though the trend is declining but seen in terms of numbers is quite large, especially those who have just graduated from education. While, the absorptive capacity of the construction sector has stagnated resulting in excess labor supply in the city. Conversely, unemployment in the village actually increased because the shifting of the workforce became a housewife [7]. The unemployment rate in the city is much higher than in the village. While, viewed from the level of education, the largest open unemployment rate at the level of Vocational High School (SMK) is then followed by the level of Diploma I/II/III. The main factor is they do not want to accept the work. On the contrary, those with low education tend to accept any work. This has the effect of increasing the open unemployment rate at the level of I/II/III Diploma education, universities and high schools [6].

This reality puts Indonesia's unemployment in second place after Brunei Darussalam. Moreover, the majority of unemployment is a productive age where young workers are vulnerable to modern industrial work patterns. The advancement of technology and machinery threatens young workers a bit [8]. Government efforts to control it by increasing their skills to be ready to enter labor competition. It's just that the government's ability is limited both from the budget for apprenticeship or labor training, so that a negative relationship occurs.

Ha: Political instability ejection a positive effect on the Indonesian government $n$

The political climate in Indonesia felt better before the reform, which was evidenced by the considerable response from foreign investors to Indonesia. The contributing factor was that the 'Orde Baru' government system was more authoritarian, which had an impact on high economic stability such as low rice prices and eventually penetrated political stability. But, after the reformation, the fragility of the economic system occurred because of changes in government regulations along with the change of government in Indonesia. This condition triggers high political instability such as chaos-chaos of people who do not obey the government that has been simultaneously elected. The riot will drive government spending will increase and ignoring other interests.

Ha: Taxes, unemployment and economic instability affects simultaneously against Indonesia government spending.

Taxes, unemployment and political instability are the main variables that affect to Indonesian government expenditure. However, these three variables cannot be separated from each other affecting the Indonesian government expenditure. The economic welfare of Indonesia requires the three independent variables to be good so that government expenditure can be controlled. The achievement of this condition will make Indonesia a developed country, which is marked by the shifting role of the government to a field that is really urgent.

\section{Conclusion}

\subsection{Conclusion}

On the tax effect equation, unemployment and political instability of the Indonesian government spending can be conclusion:

1. Taxes have a positive and significant effect on Indonesian government spending;

2. Unemployment has a negative and insignificant effect on the issuance of the Indonesian government;

3. Political institutions have a positive and significant effect on Indonesian government spending;

4. Taxes, unemployment and political instability simultaneously consequences on Indonesian government spending.

\subsection{Suggestions}

To be able to know the condition of Indonesian government spending optimally in the future, it is necessary to consider more concrete social factors.

\section{References}

[1] Amir, M. (2016), Perekonomian Indonesia Pasca Reformasi, Penerbit Erlangga.

[2] Asian Development Bank (ADB) - Key Indicators 2006 (www.adb.org/statistics)

[3] Asian Development Bank, Government Finance, http://www.adb.org/publications/key-indicators-asia-and-pacific2017.

[4] Faisal, B. (1995), Perekonomian Indonesia Menjelang Abad XXI Distorsi, Peluang dan Kendala, Penerbit Erlangga.

[5] Gujarati. (2003), Basic Econometrics, McGraw-Hill.

[6] https://ekonomi.kompas.com/read/2018/05/14/114100726/ reducing unemployment-in-Indonesia.

[7] https://www.draftgorenh.com/solusi-dan-cara-mengatasipengagalan-di-indonesia/.

[8] https://www.geogle.co.id/amp/s/beritagar.id/ artikelemp/berita/pengangguran-tertinggi-di-indonesia-adalah-anak-muda.

[9] Mudrajad, K. (2014), Otonomi Daerah Menuju Era Baru Pembangunan Daerah, Penerbit Erlangga.

[10] Munawir, I., Dwi, B. S., Ahmad, E. Y. (2014), Sistem Ekonomi Indonesia; Tafsiran Pancasila dan UUD 1945, Penerbit Erlangga.

[11] Sadono, S. (2000), Makroekonomi: Teori Pengantar, PT Raja Grafindo Persada.

[12] Simanjuntak, R. A. (2003), Berbagai Isu Penerimaan Daerah di Era Desentralisasi, Proceedings of the International Decentralization and its impact on Local Economu and Society.

[13] Sugiartiningsih. (2014), Pengaruh Pendapatan Perkapita Terhadap Pengeluaran Pemerintah di Indonesia Periode 1993-2012, Proceedings of the Seminar Nasional Fakultas Ekonomi dan Bisnis, Universitas Sebelas Maret.

[14] Sugiartiningsih. (2018), Maranatha Economics and Business Conference, Universitas Kristen Maranatha. 